\title{
PRODUCTION AND OIL CONTENT OF PHYSIC NUT (Jatropha curcas L.) FOR THE FIRST AND SECOND HARVEST YEARS IN EAST NUSA TENGGARA-INDONESIA
}

\author{
Maftuchah*a $^{\text {a }}$, Agus Zainudin ${ }^{\mathrm{a}}$, Hadi Sudarmo ${ }^{\mathrm{b}}$, Helvi Ardana Reswari ${ }^{\mathrm{a}}$ \\ ${ }^{a}$ Faculty of Agriculture and Animal Science - University of Muhammadiyah Malang, \\ East Java, Indonesia \\ ${ }^{b}$ Indonesian Tobacco and Fiber Crops Research Institute, Malang, East Java, Indonesia
}

\begin{abstract}
Jatropha curcas Linn. is one of many bioenergy plants which is potential to produce biodiesel in the tropical country. However, has not found highly potential varieties on dry land yet. The purpose of this research is to gain information of J. curcas L. seeds production and oil content on first and second harvest in East Nusa Tenggara breeding location. The research was conducted in East Nusa Tenggara province - Indonesia, with the materials used in this research are the four numbers of $J$. curcas hybrids, they are SP8 $\times$ SP16, SP $8 \times$ SP38, SP33 $\times$ HS49, SM35 $\times$ SP38, and two control accession from Indonesia Agricultural Ministry IP3A and IP3P. The SP8 $\times$ SP16 hybrid produces the highest number of fruits /plant (97.23 fruits/plant) and seeds dry weight average (179.34 g/plant) in second harvest, with dry weight of 100 seeds 71.25 gram, oil content $31.252 \%$, and first harvest time 90-91 days. And than followed by SP33 $\times$ HS49 hybrid, with average seed dry weight $123.07 \mathrm{~g} / \mathrm{plant}$, number of fruits 71.22 , oil content $30.72 \%$, but the first harvest time longer than another hybrids (101-102 day). In this research, all off hybrids produce higher seed dry weigh compare to control plant (IP3A and IP3P).
\end{abstract}

Keywords: East Nusa Tenggara, first and second harvest, hybrids, Jatropha curcas Linn.

\section{INTRODUCTION}

The increasing demand of fuel requires significant effort to develop new and renewable energy resources nationwide (Irianto, 2010). To support the utilization of bioenergy as a renewable resource, Indonesian government has declared a President Decree No. 5 of 2006 on National Energy Policy which, among other things, sets the target use of biofuels from $0.2 \%$ to more than $5 \%$ of national energy consumption by 2025 (Sardjono, 2007).

J.curcas plant is one of the pants producing energy which can be found in almost all provinces in Indonesia (Hasnam et al, 2007).

This plant has broad adaptability, grows in all types of soil, and able to withstand long periods of drought. Jatropha can survive in critical land where the availability of water and nutrients is limited or in marginal land (Ikbal et al, 2010). J.curcas is a versatile plant and all its body parts have high potential for usage. One of the advantages is that the seeds contain oil by $35-40 \%$ which can be used as biodiesel. J.curcas is also included as a plant fuel to support diversification program of alternative energy resources. J.curcas oil, in addition to its function as a source of renewable oils, is also included as non edible oil so it does not compete with human consumption needs such as palm oil and other vegetable oils. The usage of J.curcas oil as biodiesel material is seen as an ideal alternative to reduce the demand of fuel as well as to substitute diesel oil (Center for

Corresponding Author:* maftuchah_umm@yahoo.com 
Research and Development of Estate Crops, 2008).

J.curcas is categorized into Euphorbiaceae family that has high potential as a producer of biofuels, lubricating oil, raw material in the manufacture of high quality soaps, raw materials in insecticides industry, fungicides and moluskasida and as antitumor drugs. J.curcas is very prospective to be manufactured as a source of biodiesel since it has the ability to grow in less fertile soil. It has strong root system which is able to withstand ground water and can serve as barriers to erosion (Divakara et.al., 2010). Jatropha can be grown in a variety of textures and types of soil, such as in rocky, sandy, argillaceous or clay ground. Jatropha's ability to grow on dry land has not been widely studied, but the results of several studies have explained the performance of Jatropha plants under conditions of minimal water availability (Achten et.al., 2010; Pompelli et.al., 2010).

In an effort to accelerate the supply and utilization of biofuels (BBN), the President Decree followed by President Instruction No. 1 of 2006 were regulated which, among other things, instruct the Minister of Agriculture to encourage the provision of J.curcas planting. Therefore, in order to achieve a high-productivity planting materials, the producers have done various selection processes. However, quality yielding variety of planting materials has not been discovered or released until now (Hariyadi, 2005). There is not any available planting material which has production potential of more than 10 tons/ha/year (Irianto, 2010); therefore, the presence of new varieties and superior planting material are of urgency.

Plant breeding is a human activity in maintaining and producing plants' offspring while improving its quality (Salim, 2010). Attempts to obtain superior planting materials through conventional breeding activities are generally conducted through crossbreeding. The success of breeding programs to obtain planting material is determined by the richness of the available genetic resources (Hasnam et al., 2007). The presence of new individuals in the population as a result of crossbreeding can encourage variety and diversity from recombination processes in the crossbred and has a close relationship with its varied parent. Genetic diversity information is highly significant as the data base for breeding programs, conservation, evaluation, and selection of plants. The availability of high genetic diversity will allow breeders to select genetic material. Initial characterization activities have to be done before making variety repair, in order to know the identity of each individual.

Several studies have explained the behaviors of some J.curcas accessions in different environmental conditions (Achten et.al., 2010). Although Jatropha is known to have capability to grow in dry climates and marginalized area, these plants still need water and sufficient nutrients to be able to produce optimally. In commercial scale of Jatropha plant development, the availability of quality seeds is to be one of the obstacles. This is because until now there has not been obtained any Jatropha variety that has special abilities in a specific environment (Hartati, 2012). To overcome this problem, efforts should be made in Jatropha planting material through the improvement of plant breeding activities (Maftuchah et.al., 2013).

Indonesia has quite extensive potential of nonproductive dry land, especially in eastern part of Indonesia. Most of these regions have more arid climates that have not been used maximally for agricultural cultivation. These locations are very suitable for Jatropha's plantation. The research team has been conducting cross breeding to obtain 
properties of plants tolerant to drought. This activity was followed by the selection of potential hybrid products (Maftuchah et.al, 2015). Currently, four numbers featured hybrids have been selected (SP8XSP16, SP8XSP38, SP33XHS49, SM35XSP38) and proceeded with multi-location test. This study aimed to obtain information of production level and seed oil level of some J.curcas hybrids in the first and the second year of harvests in East Nusa Tenggara province.

\section{MATERIALS AND METHOD}

The research was conducted in Maumere, East Nusa Tenggara, using four different varieties of J.curcas hybrids, i.e. SP8XSP16, SP8XSP38, SP33XHS49, SM35XSP38 and two comparative crops set by the Ministry of Agriculture; they were IP3A and IP3P. Both accession comparators were high potential yielding accessions as the results of mass selection in Asembagus and Pakuwon.

The study was conducted by applying a simple Randomized Block Design (RBD), with four groups. Each group utilized 20 plant samples. The planting material used was J.curcasstem cuttings with $30 \mathrm{~cm}$ long cuttings and $2-3 \mathrm{~cm}$ in diameter. Seeding stage was done in a polybag with a diameter of $15 \mathrm{~cm}$ and a length of $20 \mathrm{~cm}$, which had been filled with soil planting medium, sand, and manure with a ratio of media 1: 1: 1 . Maintenance activities included daily seedling watering, manual weeding, fertilizing, and pest and disease control done when necessary. Treatment for plants was conducted within 2 months, until the Jatropha plant was ready to be transferred to the field.

Planting hole was made in the field with the size of $40 \times 40 \mathrm{~cm}$ and a hole depth of $40 \mathrm{~cm}$ with a spacing of $2 \times 2$ meters. At the bottom of the hole, manure was given as much as $50 \mathrm{~kg} / \mathrm{hole}$. After the age of 2 months, J.curcas seedlings were transplanted to the field. Transplanting was done during the rainy season. Observations on the plant height were conducted every month until the plant reaches two years old. Observations on the parameters of generative plants, such as the first harvest age, the number of bunches per plant, the number of fruits per plant, seeds' dry weight per plant, dry weight of 100 seeds and seed oil content were executed every time the crop enters the generative phase. This study was conducted over the past two harvest seasons. Seed oil level was then analyzed through a micro Kjeldahl method.

\section{RESULTS AND DISCUSSION}

The result presented that there was no significant difference to the life of the first crop on each J.curcas hybrid tested in East Nusa Tenggara. The test result also showed that the average age of first harvest of J.curcas $L$ hybrid was in the range of 90 to 101 days after transplanting (Table 1).

The average age of first harvest, the number of bunches, fruit, dry seed weight, and dry weight of 100 seeds of hybrid numbers from the first crop were shown in Table 1, while the second harvest details were shown in Table 2. In the first harvest, there was no significant difference in the number of fruit, whereas in the second crop, there was significant difference in the number of fruits per plant.

Duncan test results to the amount of fruit bunches indicated a difference in the first and second crop harvests, while in the parameters of the number of pieces only indicated a difference in only the second harvest. The highest number of bunches in the second crop was achieved by hybrid SP8XSP16 (producing fruit bunches of 21,286), and not significantly different in the case of SP33XHS49 
treatment (number of bunches: 15,911). Similarly, the highest number of fruits was obtained from hybrid SP8XSP16 (97.23 pieces) and was significantly different from all other treatments including the control group. The highest dry seed weight in the second harvest was also obtained from the SP8XSP16 treatment (179.34 g/plant) and it was higher than all other treatments (Table 1 and 2).

Jatropha is a perennial plant that is relatively tolerant to drought. However, the level of Jatropha production is influenced by genetic potential, environmental conditions and crop management level (Ratree, 2004). Observation of the level of production and quality of Jatropha can be done via the measurement of the parameter number of fruits per plant, dry seed weight per plant, dry weight of 100 seeds and seed oil content.

Jatropha can be generatively cultivated by seed and vegetatively grown by planting stem cuttings. Plants from cuttings tend to bloom their flower faster than that derived from seeds, it is because the plants derived from the seeds must go through a juvenile phase (Sudhakara, et.al., 2012). Results of other studies have also shown that Jatropha derived from vegetative propagation will enter the flowering phase faster than propagated from seed.

Table 1. The average age of first harvest, the number of fruit bunches, fruit number, dry seed weight, dry weight of 100 seeds of J.curcashybrids on the first harvest in Maumere, East Nusa Tenggara.

\begin{tabular}{|c|c|c|c|c|c|c|c|c|}
\hline \multirow{2}{*}{$\begin{array}{l}\text { Accessions } \\
\text { SP8XSP16 } \\
\end{array}$} & \multicolumn{2}{|c|}{$\begin{array}{c}\text { Age of First } \\
\text { Harvest } \\
\text { (HST) }\end{array}$} & $\begin{array}{c}\sum \text { fruit bunches } \\
\text { per plant }\end{array}$ & \multicolumn{2}{|c|}{$\begin{array}{l}\sum \text { fruit per } \\
\text { plant }\end{array}$} & \multicolumn{2}{|c|}{$\begin{array}{c}\text { Dry Seed } \\
\text { Weight(gram/plant) }\end{array}$} & $\begin{array}{c}\text { Dry weight for } \\
100 \text { seeds } \\
\text { (gram) }\end{array}$ \\
\hline & 90.041 & $\mathrm{a}$ & $16.10 \mathrm{ab}$ & 26.989 & $\mathrm{a}$ & 44.87 & $\mathrm{a}$ & $66.167 \quad \mathrm{ab}$ \\
\hline SP8XSP38 & 96.696 & $\mathrm{a}$ & $14.57 \quad \mathrm{ab}$ & 23.526 & $\mathrm{a}$ & 36.60 & $a b$ & 66.083 \\
\hline SP33XHS49 & 101.330 & $\mathrm{a}$ & $13.65 \mathrm{ab}$ & 23.733 & $\mathrm{a}$ & 38.90 & $\mathrm{ab}$ & 68.417 \\
\hline SM35XSP38 & 94.821 & $\mathrm{a}$ & $18.44 \quad \mathrm{a}$ & 27.695 & $\mathrm{a}$ & 47.63 & $\mathrm{a}$ & 70.125 \\
\hline IP3A & 99.754 & $\mathrm{a}$ & $6.98 \quad \mathrm{~b}$ & 11.467 & $\mathrm{a}$ & 9.83 & $\mathrm{~b}$ & 62.833 bc \\
\hline 1P3P & 96.842 & $\mathrm{a}$ & $9.61 \mathrm{ab}$ & 14.980 & $\mathrm{a}$ & 17.60 & $\mathrm{ab}$ & $59.833 \mathrm{c}$ \\
\hline
\end{tabular}

Notes: HST=days after transplanting to the field; BK = Dry Weight; the numbers followed by the same letter in the same column are not significantly different at $5 \%$ Duncan test.

Table 2. The average number of fruit bunches, fruit number, dry seed weight, dry weight of 100 seeds of J.curcas hybrids on the second harvest in Maumere, East Nusa Tenggara.

\begin{tabular}{|c|c|c|c|c|c|}
\hline Accessions & $\sum$ fruit bunches per plant & $\begin{array}{l}\sum \text { fruit per } \\
\text { plant }\end{array}$ & & $\begin{array}{l}\text { Dry Seed Weight } \\
\text { (gram/plant) }\end{array}$ & $\begin{array}{c}\text { Dry weight } \\
\text { for } 100 \text { seeds } \\
\text { (gram) }\end{array}$ \\
\hline SP8XSP16 & $21.286 \quad \mathrm{a}$ & 97.23 & $\mathrm{a}$ & $179.34 \quad \mathrm{a}$ & $71.25 \quad \mathrm{a}$ \\
\hline SP8XSP38 & $14.411 \quad b c$ & 62.53 & $\mathrm{bc}$ & 80.11 bc & 56.67 \\
\hline SP33XHS49 & $15.911 \mathrm{ab}$ & 71.22 & $\mathrm{~b}$ & $123.07 \quad b$ & 72.50 \\
\hline SM35XSP38 & 12.155 bc & 51.73 & $\mathrm{bc}$ & 89.05 bc & $55.63 \quad$ a \\
\hline IP3A & $9.060 \mathrm{c}$ & 43.68 & $\mathrm{c}$ & $65.66 \mathrm{c}$ & 49.58 \\
\hline 1P3P & $9.291 \quad \mathrm{c}$ & 41.21 & $\mathrm{c}$ & 73.64 bc & 50.83 \\
\hline
\end{tabular}

Notes : BK= Dry Weight; The numbers followed by the same letter in the same column are not significantly different at 5\% Duncan test.

The number of productive branches on J.curcas will determine the productivity of the plant (Ratree,
2004). J.curcas seed production in the first year may reach 318 g/plant (Heller, 1996). In India, 
J.curcas starts its production in the second year and is able to produce seeds from 0.4 to 12 tonnes/ha (Lele 2005). If planted as a hedge plant, Jatropha seed production ranged between $0.8-1.0 \mathrm{~kg}$ of seeds/plant, equivalent to 2.5-3.5 tonnes/ha/year (Henning, 2004). Based on the potential oil production of $1,590 \mathrm{~kg}$ oil/ha/year derived from the seeds of Jatropha, the production achieved in this study would be lower. However, in this research, Jatropha cultivation was done on land that is the dry land of East Nusa Tenggara which generally cannot be used for cultivation.

In the first harvest, the dry weight of 100 seeds reached by Jatropha hybrids ranged from 66,083 up to 70,125 grams. The four tested hybrids produced the dry weight of 100 seeds higher than the IP3P IP3A control plants. Whereas in the second harvest, the dry weight of 100 seeds did not indicate any difference among all tested treatments (Table 1 and Table2).

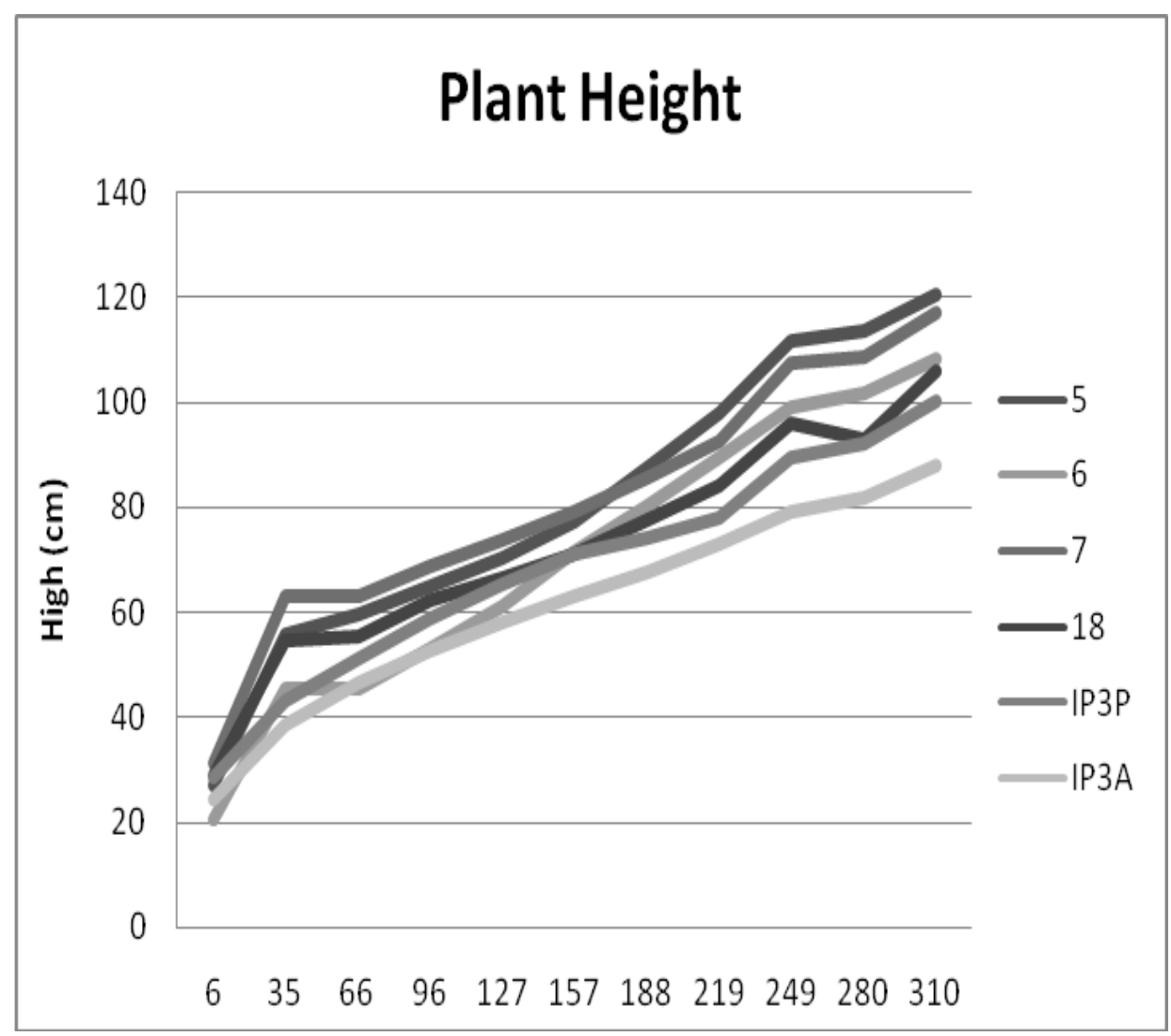

Figure 1.The Height of J.curcas L. hybrid varieties in Maumere-East Nusa Tenggara at the age of 6 up to 310 days after transplanting. 


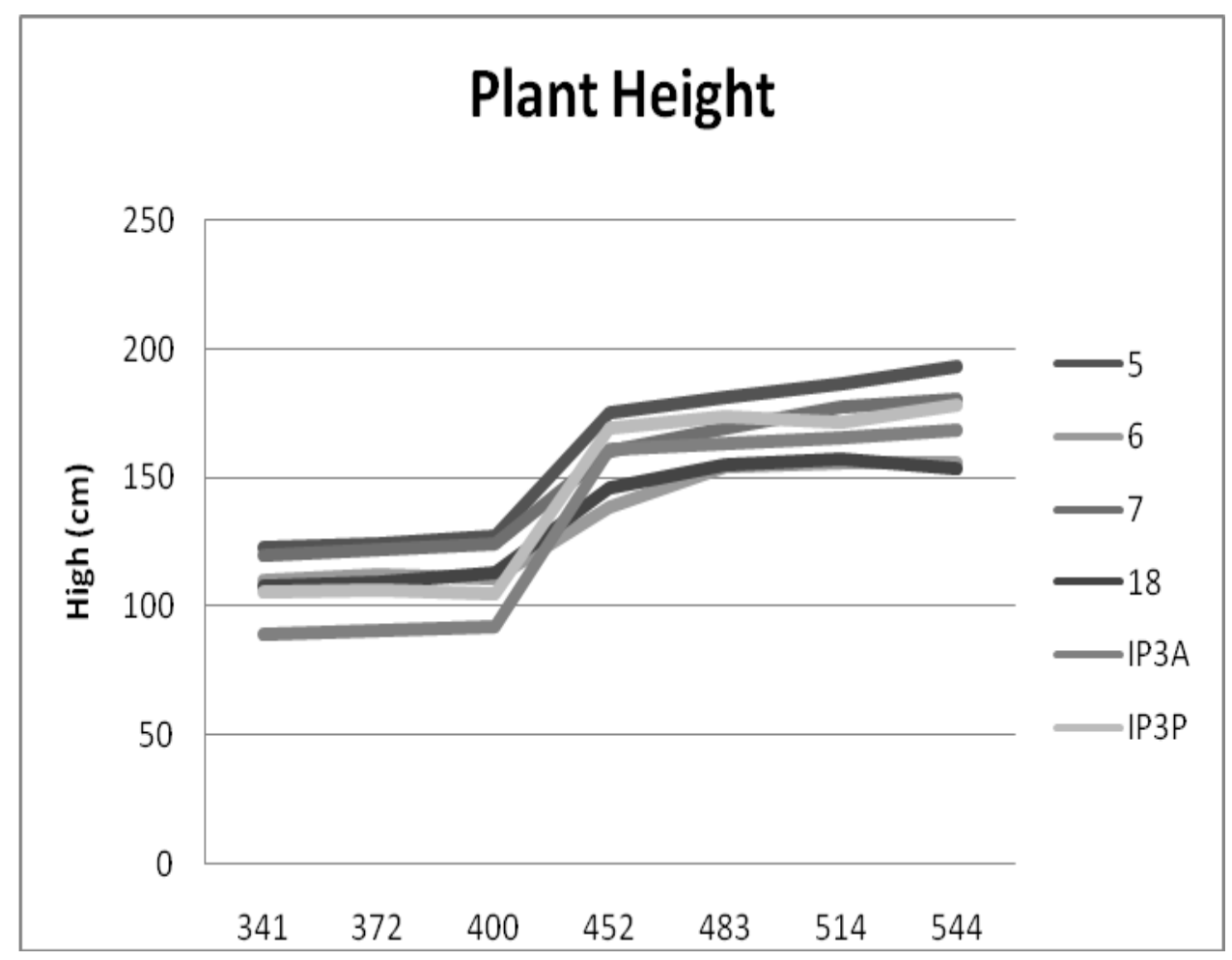

Figure 2.The Height of J.curcas L. hybrid varieties in Maumere-East Nusa Tenggara at the age of 341 up to 544 days after transplanting.

Data of plant height from varieties of J.curcas L. hybrid, which were tested in East Nusa Tenggara field at the age of 6 to 310 days and 341 up to 544 days after transplanting, were shown in Figures 1 and 2. In this study, the planting of Jatropha was implemented by using trunk cuttings which was about $30 \mathrm{~cm}$ long. Plant height growth charts showed that the average plant height achieved by J.curcas SP8XSP16 hybrid was higher than the other three hybrids and plant control. The figure also interpreted that upon entering the generative phase, Jatropha plants displayed a reduction in the growth rate of its height, compared to the beginning of the growing season (Figure 2)

Table 3. Average seed oil level of J.curcas L hybrids on the first and second harvests in Maumere, East Nusa Tenggara.

\begin{tabular}{|c|c|c|}
\hline Accessions & $\begin{array}{l}\text { Oil Level of First Harvest } \\
(\% \text { dry seed })\end{array}$ & $\begin{array}{c}\text { Oil Level of Second Harves } \\
(\% \text { dry seed })\end{array}$ \\
\hline SP8XSP16 & $36.336 \quad \mathrm{a}$ & 31.252 \\
\hline SP8XSP38 & $36.511 \quad \mathrm{a}$ & 30.190 \\
\hline SP33XHS49 & $36.455 \quad \mathrm{a}$ & 30.717 \\
\hline SM35XSP38 & $37.210 \quad \mathrm{a}$ & 29.232 \\
\hline IP3A & $33.232 \mathrm{~b}$ & 28.180 \\
\hline 1P3P & $33.537 \quad b$ & 29.304 \\
\hline
\end{tabular}

Notes : BK= Dry Weight; The numbers followed by the same letter in the same column are not significantly different at $5 \%$ Duncan test

The average oil level of J.curcas hybrids' seed varieties on the first and second harvests in Maumere, East Nusa Tenggara, are presented in
Table 3. The observation of seed oil level of J.curcas projected a difference in the first year observation. Duncan test results showed that the 
four tested hybrids provided higher production of oil than the control plants. Oil level in the tested seeds of hybrid plants ranged from 36,336 to 37,210 percent of their dry weight; while in the second year of harvesting, seed oil level analysis did not show any significant differences (Table 3).

The higher number of fruit bunches and total fruits in each bunch tend to be followed by higher dry weight. This is consistent with results of previous studies, proving that the characters which have positive correlation with dried seed yielding potential and have more prominent heredity value are: leaf width, number of primary branches, number of secondary branches, total of bunches per plant and the number of fruit per plant. Therefore, these characters can be used as selection criteria in planting J.curcas (Zainudin et. al., 2014).

In one research on Jatropha's yielding potential in West Lombok, West Nusa Tenggara, it was reported that the production potential of the seeds in the first year could reached $189.86 \mathrm{~g} /$ cuttings from the origin plant, and $170.75 \mathrm{~g} /$ plant from seeds (Sudhakara et.al. 2012). Compared to the previous data, the potential results obtained in this study could be lower. However, in the course of this research, irrigation for plant was not given at all in order to test the sustainability of plant growth and to check potential yielding crop under severe drought.

\section{CONCLUSION}

This study results showed that SP8XSP16 hybrid plant produced the highest number of fruit/plant (97.23 fruit/plant) and the highest average dry weight of seed (179.34 g/plant) in the second harvest, with a dry weight of 100 seeds of 71.25 grams, with seed oil level of 31.252 percent and the age of first harvest on 90-91 days after transplanting. It was then followed by SP33XHS49 hybrid, with an average weight of 123.07 grams of dry seed/plant, with total fruit of 71.22 , oil level of $30.72 \%$, but the age of first harvest was longer than the other hybrids (101-102 days). In this study, the overall tested hybrids produced dry seed weight higher than the control plants (IP3A and IP3P).

\section{ACKNOWLEDGEMENT}

This study was funded by the Directorate General of Higher Education through Excellence Research Scheme of Higher Education for 2013 fiscal year. A sincere thank is delivered to the head and staffs of Research Institute for Agricultural Technology (BPTP) of East Nusa Tenggara province on aiding the maintenance and observations of planting and harvesting during the study.

\section{REFERENCES}

Achten WMJ, Verchot L, Franken, Mathijs YJ, Singh E, Aerts VP, Muys R, 2010. Jatropha biodiesel production and use. Biomass and Bioenergy, 32 : 1063-1084

Center for Research and Development of Estate Crops. 2008. International Conference of Jatrophacurcas. Info Tek Perkebunan.Volume 3, no.8, Agustus 2008.Hal.29. Agency for Agricultural Research and Development. Estate Crops Research and Development Center.

Divakara BN, Upadhyaya HD, Wani SP, Gowda CLL, 2010. Biology and genetic improvement of Jatrophacurcas L.: a review. Applied Energy 87 : 732-742.

Hariyadi, 2005, Jatrophacurcas culture for Biofuel Alternative Source. Research and Technology Ministry, Republic Indonesia, 14-15 September 2005.

http://www.ristek,go.id/?modul=News+news\&id=96 8. Diakses 16 November 2012.

Hartati, 2012.Many important characters for increasing Jatrophacurcas., L. variety. The Proceeding of $3^{\text {th }}$ Workshop: Technology Innovation of Jatropha. Center for Research and Development of Estate Crops, Malang, 5 November 2007 : 66-69.

Hasnam, Syukur C, Hartati S, Wahyuni S, Pranowo D, Susilowati S.E, Purlani E, Heliyanto B. 2007. Jatrophacurcas L.Seed Production in Indonesia.The 
Proceeding of $3^{\text {th }}$ Workshop: Technology Innovation of Jatropha. Center for Research and Development of Estate Crops, Malang, 5 November 2007:28-36.

Henning R.K., (2004) Jatrophacurcas L. in Africa. Case Study.Weissenberg, Germany, Bagani.

Ikbal, Boora K.S. and Dhillon, R.S. 2010.Evaluation Of Genetic Diversity InJatrophacurcas L. Using Rapd Markers. Indian Journal of Biotechnology. Vol 9: 50-57.

Irianto, G. 2010. Innovation Technology and Pioneer Custer forEnergiVillage Based on Jatropha. Proceeding $5^{\text {th }}$ Workshop.The Institute of Tobacco and Fiber Crops Research.Malang : 11-13

Lele S. 2005. The cultivation of Jatrophacurcas. Research J-22, Sector, Vashi, NaviMumbai : 24-26

Maftuchah, Zainudin A, Sudarmo H. 2013. Production of physic nut hybrid progenies and their parental in various dry land. Agricultural Sciences Journal, 4(1) : 48-56.

Maftuchah, Reswari HA, Ishartati E, Zainudin A, Sudarmo H. 2015. Heretability and Correlation of Vegetative and Generative Character on Genotypes of Jatropha (JatrophacurcasLinn.). Energy Procedia, $65: 186-193$

Pompelli MF, Barata-Luis R, Vitorino HS, Goncalves ER, Rolim EV, Santos MG, Almeida-
Cortez JS, Ferreira VM, Lemos EEP, and Endres L 2010. Photosynthesis Photoprotection and Antioxydant Activity of Purging Nut Under Drought Deficit and Recovery. Biomass and Bioenergy 34:1207-1215.

Ratree, 2004.. A Preliminary Study on Physic Nut (J. curcas L.) in Thailand. Pakistan J. of Biological Sci. 7:1620-1623.

Salim, F. 2010. Genetic Deversification Analysis of Jatrophacurcas L. Accession and Wildtype Based on RAPD.Tesis.University Malang.

Sudhakara K, Rajeshb M, Premalatha M. 2012. Carbon Mitigation Potential of Jatropha Biodiesel in Indian context. Energy Procedia14 : 1421-1426.

Sardjono, M. 2007. The Development of Jatrophacurcas.The Proceeding of $3^{\text {th }}$ Workshop: Technology Innovation of Jatropha. Center for Research and Development of Estate Crops, Malang, 5 November 2007 : 19-26.

Yulaikah, S. Purwati R.D. 2009. Morfology Characterization of Jatrophacurcas LGerm Plasm.Proceeding $5^{\text {th }}$ Workshop Technology Innovation and Pioneer Cluster Base on Jatropha. Center for Research and Development of Estate Crops, Malang :71-75. 